\title{
ÉCFRASE COMO EXEMPLO DE PINTURA
}

\author{
RICARDO ZANCHETTA* \\ Universidade de São Paulo
}

\begin{abstract}
Resumo. Algumas écfrases, que descreveram pinturas dos grandes pintores da antiguidade, como Apeles e Zêuxis, foram lidas e pintadas no século XV. Esse artigo visa mostrar algumas relações entre a pintura e a écfrase, explorando o uso que Leon Battista Alberti faz, em seu Da Pintura, da Calúnia de Apeles descrita por Luciano, elegendo-a como um exemplo de pintura. Tal écfrase não só evidencia os preceitos ensinados, como também impele o pintor a imitar o louvor da pintura antiga.
\end{abstract}

Palavras-chave. Pintura; Retórica; écfrase; Renascimento; Alberti.

D.O.I. 10.11606/issn.2358-3150.v18i1p114-126

NeSSE TEXTO FALAREMOS SOBRE UM dOS USOS DAS ÉCFRASES DE PINTURA no século XV, como a Calúnia de Apeles descrita por Luciano e pintada por diversos pintores, por exemplo, Botticelli. A fim de entendemos como era concebido o uso das écfrases na pintura, analisaremos o Da Pintura de Leon Battista Alberti, pois ele foi fundamental para toda a doutrina da pintura a partir do século $\mathrm{xV}$ ao conceber a pintura como algo capaz de narrar uma história.

Porém, antes de falarmos das prescrições e regras da pintura de écfrases, precisamos entender o que é uma écfrase e o que ela apresenta de interessante para o pintor. E para isso usaremos as prescrições presentes nos Progymnásmata de Nicolau, o Sofista, onde ele explica como fazer uma écfrase de uma pintura ou escultura, indicando aquilo que é característico desse tipo de écfrase. Comecemos, então, pela sua definição de écfrase:

Écfrase é o discurso descritivo, que conduz aquilo que é mostrado claramente (enargōs) sob os olhos. Adiciona-se "claramente" porque isso certamente diferencia a écfrase da narração. Pois a última tem simplesmente os feitos de ontem, enquanto a primeira tenta fazer dos ouvintes espectadores. (...) E a écfrase também se diferencia da narração porque a última examina no todo, enquanto a primeira examina por partes. ${ }^{1}$

- Mestre em Filosofia pela Universidade de São Paulo (2014).

". Artigo recebido em 05.ago.2015 e aceito para publicação em 31.out.2015.

${ }^{1}$ Nicol. Prog. L. Spengel (1856). Rhetores Graeci 3. Leipzig: Teubner: 491-2. Tradução nossa. 
A característica principal da écfrase é a sua capacidade de saltar aos olhos, de fazer dos ouvintes espectadores, tornando vívido o discurso. Além disso, nela as coisas são descritas por partes ou em detalhe, de modo que cada coisa presente na écfrase é particularizada de alguma maneira. Por exemplo, “desse modo se diz narrativamente: 'Os atenienses e os peloponenses guerrearam.' Por outro lado, diz-se na maneira da écfrase o que cada um dos dois fez, da preparação e das armas." ${ }^{2}$ Essa descrição das partes faz o discurso ganhar vividez e quase vemos a obra, porque sabemos onde está cada parte daquilo que é descrito. E a écfrase se distingue da narração, pois a última conta os feitos no geral, enquanto a primeira passa pelas partes e detalhes daquele mesmo feito, o que torna a descrição clara e vívida como se estivesse diante dos olhos.

Nicolau também prescreve como fazer a écfrase de pinturas e esculturas:

Começaremos a partir das primeiras coisas e então chegaremos até as finais. Por exemplo, se temos na substância de uma écfrase um homem como no bronze ou na pintura, faremos a écfrase do princípio a partir da cabeça e depois prosseguimos por cada parte. Pois assim o discurso torna-se vívido (empsykhos) por todos os lados. ${ }^{3}$

Ou seja, a écfrase descreve cada parte em ordem permitindo que o ouvinte/ leitor conceba com clareza e vividez a obra que é descrita, colocando cada coisa, personagem e detalhes em seu lugar. A Calúnia de Luciano é um exemplo disso, porque ela mostra a pintura começando por um lado e descrevendo cada parte dela com suas personagens, roupas, poses e movimentos até o outro lado.

Portanto, a écfrase busca fazer do ouvinte/leitor um espectador colocando a obra diante dos olhos, o que torna ela muito interessante para os pintores que poderão imitá-la e emulá-la ao lerem essa descrição.

Agora que sabemos minimamente o que uma écfrase oferece para o pintor, podemos verificar como os pintores usaram-nas ao fazer suas pinturas. Uma das maneiras de verificar um desses usos é através dos tratados de pintura que contêm prescrições sobre como pintar. Nós analisaremos aqui algumas passagens do tratado Da Pintura de Leon Battista Alberti, escrito por volta de 1436 , porque ele propõe que a pintura tem um aspecto narrativo e retórico, capaz de mostrar uma história.

Propor a história como parte da pintura é fundamental para entender como a écfrase opera no tratado e nas pinturas que foram feitas segundo as suas prescrições, porque a écfrase fornece a descrição de uma

${ }^{2}$ Nicol. Prog. Spengel $(1856,492)$.

${ }^{3}$ Nicol. Prog. Spengel $(1856,492)$. 
história que será usada pelo pintor ao compor sua pintura. Vale aqui ressaltar que nos deteremos às écfrases que descrevem alguma ação, pois elas são escolhidas por Alberti para exemplificar sua noção de história. Por isso excluímos outros tipos de écfrases, como as Xenias, onde se descreve algo que se assemelha ao que é chamado de natureza morta.

Uma das definições de pintura apresentada por Alberti a caracteriza "como uma janela aberta a partir da qual a história será vista" (§19). ${ }^{4}$ Nesse trecho do tratado mostra-se o duplo aspecto da pintura: o primeiro se refere à construção matemático-geométrica da visão com a proporção e perspectiva; o segundo consiste em mostrar a história, ou seja, mostrar uma ação na superfície pintada. A pintura é a arte que usa tanto a geometria como a retórica no seu fazer, de modo que essas coisas estejam ligadas na obra sem que o observador separe o que é a parte geométrica da retórica. Nós, entretanto, nos focaremos nos aspectos retóricos e poéticos da pintura, porque neles que se articulam as noções que fundamentam o uso da écfrase através da história e da composição.

Alberti divide a pintura em três partes: a circunscrição, a composição e a recepção de luzes. Em poucas palavras, a primeira lida com o que chamaríamos hoje de desenho, fazendo o tracejado das figuras que serão pintadas. A segunda organiza tudo que está dentro da pintura e o que é mostrado em sua história. E na terceira são colocadas as luzes, sombras e as cores nas superfícies. A pintura só é pintura quando essas três partes são feitas até o fim tornando a superfície pintada naquela janela que mostra uma história com profundidade, relevo, etc.

A composição é a parte que nos interessa aqui, porque nela que se estabelece o vínculo entre a pintura e a retórica, trazendo para a primeira alguns elementos da segunda. Mesmo assim, ressaltamos que sempre que se observa uma pintura que, em alguma medida, siga as preceptivas de Alberti, devemos lembrar que a obra é um todo e que a análise não deve se restringir apenas aos aspectos retóricos ou aos geométricos.

A composição consiste na "razão para pintar com a qual as partes das coisas vistas se colocam juntas na pintura" (\$35). Ou seja, é uma razão, um preceito, um método ou uma série de regras usadas para pintar na qual as coisas vistas são organizadas e ajustadas convenientemente na pintura. Nela, tudo que será pintado é composto e colocado junto de maneira conveniente, desde as menores superfícies até a história. Por isso a composição é subdividida em vários níveis, em que se prescreve como juntar aquelas partes para fazer o composto. “Os corpos são partes da história, os membros

${ }^{4}$ Alberti 1973, tradução nossa. A partir desse ponto todas as referências ao Da Pintura serão indicadas pelo número do parágrafo. 
são partes dos corpos, a superfície é parte dos membros" (\$35). A composição opera em todos esses níveis desde a superfície até a história e cada nível possui seus preceitos específicos

Todas as partes da composição visam à história de modo que tudo na pintura deve estar de acordo com o que acontece em todos os níveis da composição. Por exemplo, quando se compõe os membros em um corpo, é conveniente que eles apresentem certa unidade quanto à especificidade ou à aparência: "Quem pintasse Aquemênidas encontrado por Enéias na ilha com a face da maneira como Virgílio descreve que estava e as outras partes não seguissem a conveniência da face, esse pintor, com efeito, seria totalmente ridículo e inepto" (\$37). Outro exemplo de conveniência da história é que "se tiveres pintado centauros tumultuando em um jantar, seria inepto em um tumulto tão selvagem, alguém deitar dormindo por causa do vinho" (\$39).

Essas prescrições ensinam o pintor a fazer com que a pintura seja narrativa, trazendo para ela algumas noções retóricas e poéticas, de modo que aquelas linhas e tintas narrem uma ação. Além disso, operam junto com a composição noções como a invenção, a disposição e a elocução, que são fundamentais para entendermos como a pintura se relaciona com os textos e como Alberti propõe o uso das écfrases. ${ }^{5}$

A história é a noção mais importante para compreender como a pintura mostra uma narração: "A história merecedora de elogio e admiração, deverá com seus atrativos se apresentar de tal forma ornada e agradável que conquistará, pelo deleite e movimento da alma, a todos que a contemplem, doutos ou indoutos" (\$40) A pintura e a história que ela mostra devem deleitar, comover e conquistar o espectador ensinando aquilo que se passa em sua história. Por isso, o fim da pintura não é a persuasão nem a apresentação de coisas verdadeiras, já que ela busca conquistar quem a olha, deleitando e comovendo.

E não é um problema para Alberti um pintor fazer uma obra de algo que não exista como um hipocentauro ou uma pintura alegórica sem que isso signifique que o pintor possa fazer qualquer coisa, porque ele deve "ter sempre na sua frente algum exemplo elegante e singular para observar e retratar/imitar" (§59). Ou seja, nada na pintura deve ser tirado exclusivamente da imaginação do pintor, porque há razões que regulam a pintura, inclusive para encontrar aquilo que será pintado. A "descoberta de coisas verdadeiras ou verossímeis que tornem a causa provável”' se chama invenção e na pintura é preciso inventar coisas convenientes e dignas desde as

${ }^{5}$ Ainda não conseguimos determinar com precisão a relação entre a composição, a invenção e a disposição e qual hierarquia se estabelece entre essas noções no Da Pintura.

${ }^{6}$ Her., 1.3 (Ps.-Cícero, 2005, 55). 
superfícies até a própria história a partir de algum exemplo. No entanto, esses exemplos podem ser inventados de textos e por isso Alberti prescreve a convivência do pintor com os letrados da seguinte maneira:

Em seguida, não é fora de propósito que [o pintor] se deleite com os poetas e retores. Pois, com efeito, eles têm muitos ornamentos comuns com o pintor. Eles, muito letrados e com conhecimento de muitas coisas, ajudarão muito para constituir belamente a composição da história, a qual todo o louvor consiste principalmente na invenção. E, com efeito, ela tem tal força que mesmo sozinha, sem a pintura, deleita. (§53)

O pintor deve frequentar os poetas e os retores, porque eles têm coisas em comum como a invenção e os ornamentos, e a convivência, tanto presencial como pelos textos é de muita ajuda para aumentar o repertório de coisas inventadas pelo pintor. Por exemplo, um pintor que conhece as Metamorfoses de Ovídio, adquire um vasto repertório de invenções de corpos e de histórias, pois aprende com as descrições como pintar os deuses, os heróis e suas histórias.

Ao propor que o pintor pode inventar sua pintura a partir de poemas e discursos, Alberti estabelece uma maneira de trazer para a pintura as coisas mostradas pelos textos. A écfrase serve como fonte de invenção para o pintor que ao ler se deleita com aquilo e adquire um repertório para as coisas que irá pintar, inventando a sua pintura com as partes descritas. Pois ela mostra a obra e descreve as suas partes, indicando onde está cada pessoa e coisa e qual seu movimento, seus gestos, suas roupas e tudo isso será imitado na pintura.

E não é só a invenção que o pintor usa, porque os ornamentos são comuns aos pintores, poetas e retores. ${ }^{7}$ Supomos que uma das maneiras de usar os ornamentos comuns dessas artes está na variedade e copiosidade das coisas mostradas. Pois a história deve deleitar e uma das maneiras que Alberti propõe para isso é que tudo na pintura seja variado e copioso. "Direi que é copiosíssima a história que em seus lugares houverem misturados velhos, homens, adolescentes, crianças, matronas, moças, infantes, animais domésticos, cãezinhos, passarinhos, cavalos, rebanhos, edifícios e províncias" (§40). Essa variedade deleita e chama a atenção do espectador fazendo-o se deter em cada detalhe, porque cada parte da pintura é diferente da outra. Toda essa variedade e copiosidade também pode ser obtida das écfrases, porque, segundo Nicolau, a descrição deve mostrar cada parte e detalhe a fim de fazer a écfrase vívida e todas essas partes podem ser pintadas tornando a pintura copiosa.

${ }^{7}$ Ainda não examinamos profundamente o que Alberti propõe com essa noção de ornamentos comuns e aqui apresentamos nossa hipótese inicial. 


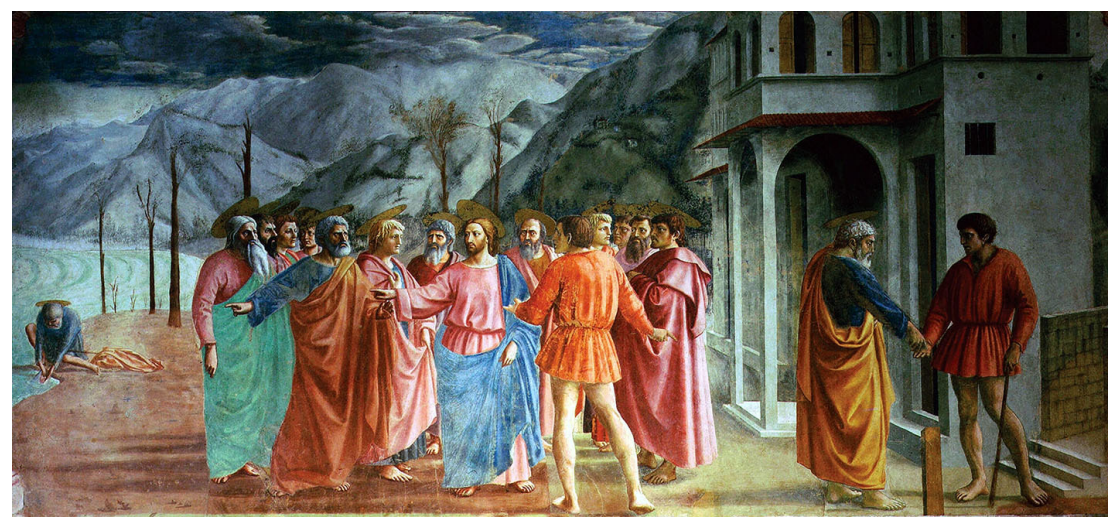

Figura 1. Masaccio, Pagamento do Tributo, afresco, c.1425

Entretanto, devemos estar cientes de que Alberti restringe a vivência com poetas e retores à invenção e aos ornamentos comuns usados para fazer a história, porque como são artes distintas, cada uma tem seus preceitos e todo o resto é feito com as regras da pintura. Ressaltamos esse ponto, porque aqui não opera uma estétita universal e comum a todas as artes, em que tudo é transponível de uma arte para outra. Pelo contrário, a doutrina de Alberti ensina a adotar elementos de outras artes, usando-as como disciplinas ancilares da pintura.

Um exemplo disso está na disposição da écfrase e da pintura. A écfrase é um discurso e por isso mesmo deve ser lida ou ouvida em uma ordem determinada pelo próprio discurso, que começa pela primeira linha prosseguindo até a última. Assim, a disposição do texto é seguida pelo ouvinte/leitor e sem isso o discurso perde todo o sentido, exigindo que o leitor possua educação suficiente para entender por onde deve começar sua leitura.

A pintura também tem uma "ordem" para olhar que depende da maneira como ela foi disposta e há prescrições que ensinam como o pintor deve indicar o começo de sua pintura e onde se deve olhar primeiro. Quem olha uma pintura precisa ser educado para isso, de modo que saiba ver como ela é construída para entendê-la. A construção em perspectiva exige que o observador olhe para o ponto cêntrico (ou ponto de fuga) com um olho para que a construção seja vista corretamente e que se tenha a impressão da profundidade. O ponto cêntrico é o ponto principal da pintura e sempre se deve olhar nele para ver qualquer obra que possua perspectiva e tudo que é colocado próximo dele deve ser visto em primeiro lugar.

Por exemplo, no pagamento do tributo de Masaccio (FIGURA 1) há uma história contada em três momentos inventada da seguinte passagem bíblica: "Mas, para que não os escandalizemos, vai ao mar e joga o anzol. $\mathrm{O}$ 


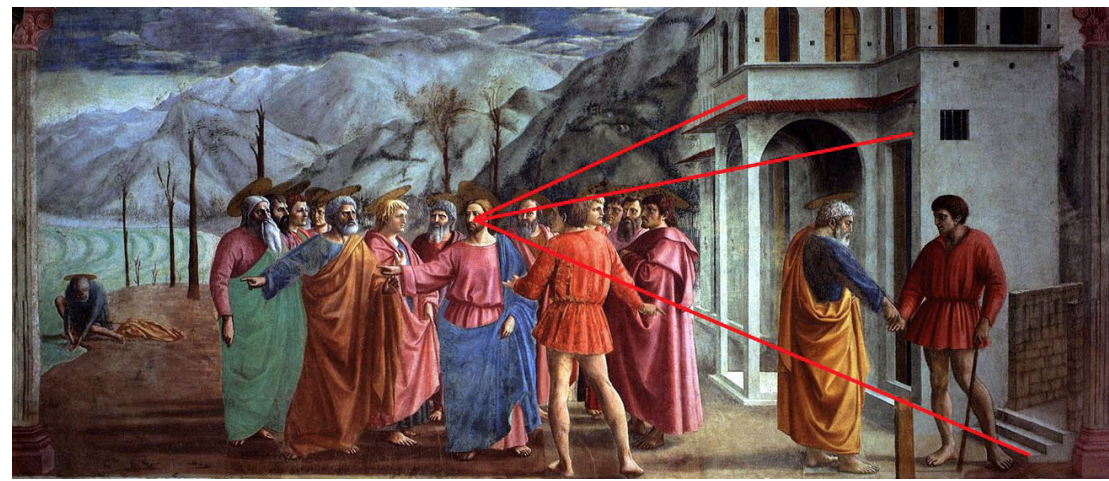

Figura 2. Esquema da construção em perspectiva e ponto de fuga

primeiro peixe que subir, segura-o e abre-lhe a boca. Acharás aí um estáter. Pega-o e entrega-o a eles por mim e por ti." ${ }^{\prime 8}$

Masaccio traz para a pintura os três momentos descritos na Bíblia e usa alguns artifícios para mostrar qual a ordem em que eles devem ser olhados; No centro está Jesus com os apóstolos e o ponto cêntrico está exatamente na cabeça de Cristo, mostrando que ele é a figura principal e ele deve ser a primeira coisa para se ver (FIGURA 2). Ali está o primeiro momento da história com todos parados em frente a cidade esperando para pagar o tributo.

Tanto Jesus como Pedro apontam para o lado esquerdo da pintura (FIGURA 3), onde Pedro encontra o peixe com a moeda que servirá para pagar a entrada, mostrando ao espectador para onde ele deve olhar. Esse gesto de indicar é prescrito por Alberti para ajudar o espectador a aprender a história. “Então agrada na história haver alguém que advirta aos espectadores das coisas que acontecem ou convide para ver com a mão ou ameace com olhos selvagens

${ }^{8}$ N.T., Ev. Matt., 17, 27.

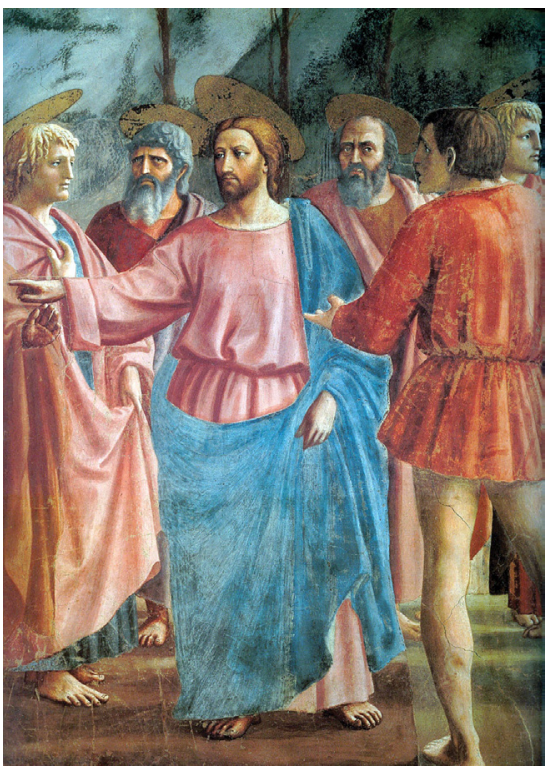

Figura 3. Detalhe do Pagamento do Tributo 
e rosto feroz para que tu não vás ali, como se quisesse manter aquele negócio secreto" (\$42).

E por fim vemos a figura à direita de Jesus que aponta para a cidade, mas reparamos nela depois, porque ela recebe menos destaque que Jesus e Pedro. Essa pintura possui uma "ordem" de observação que está explicada dentro dela mesma e é feita na própria composição da pintura o que permite que a história seja "contada" em três momentos.

Obviamente, o olhar é livre e adora passear pela pintura e não precisa seguir essa ordem, mas alguém instruído nessa arte percebe a ordem proposta pelo pintor. Ressaltamos que isso não se opera em qualquer pintura, porque cada uma é feita de uma maneira e é preciso analisar cada uma para verificar se é possível falar em composição e disposição e como ela é usada dentro da pintura.

Há, portanto, coisas que podem ser tomadas das écfrases na hora de compor uma história, como a invenção e os ornamentos, enquanto outras coisas seguem as regras próprias da pintura, como a construção em perspectiva, e Alberti ensina como e o que os pintores devem usar das écfrases para fazer suas pinturas. Além disso, a écfrase possui um papel especial no Da Pintura, uma vez que foi eleita o exemplo da pintura de história.

Alberti elege a écfrase como o exemplo de invenção, porque ela tem tudo aquilo que deve ser buscado numa boa composição e logo após a passagem que citamos, ele narra a Calúnia de Apeles, que Luciano "conta ter sido pintada por Apeles" (\$53). A Calúnia é um exemplo tanto dos benefícios que o pintor tira ao conviver com poetas e retores, como também da invenção de uma bela composição de história.

Propor a Calúnia como exemplo coloca diante dos olhos dos pintores tudo aquilo que foi prescrito no Da Pintura, mostrando com palavras no que consiste uma bela composição pictórica, já que a écfrase salta aos olhos daqueles que a ouvem/lêem. E mais do que isso, ela também serve ao ensino da pintura, porque o pintor precisa conhecer a doutrina e ter exemplos para imitar e emular.

No prólogo italiano, Alberti louva a grandeza dos italianos exatamente porque eles conseguiram fazer a pintura renascer sem ter nem as doutrinas, nem os modelos disponíveis para imitar:

Confesso-te, sim, que para aqueles antigos, tendo a abundância de quem aprender e imitar como tinham, era menos difícil alçar-se no conhecimento daquelas supremas artes que hoje para nós são fatigosíssimas; mas por isso mesmo o nosso nome deve ser muito maior, se nós, sem preceptores, sem nenhum exemplo, encontramos artes e ciências não ouvidas e nunca vistas.

A doutrina e os exemplos são duas maneiras de aprender a arte da pintura, de maneira semelhante ao que diz a Retórica a Herênio: 
Tudo isso [a arte retórica] poderemos alcançar por três meios: arte, imitação e exercício. Arte é o preceito que dá o caminho certo e a razão para dizer. Imitação é o que nos impele, com razão (método) diligente, a que logremos a ser semelhantes a outros no dizer. Exercício é a prática assídua e o costume de discursar. ${ }^{9}$

Alberti supre a doutrina com o seu Da Pintura, já que ele ensina as regras da arte: a Calúnia de Apeles é o exemplo da pintura que tem tudo aquilo que foi ensinado na doutrina e o pintor deve admirá-la para tentar ser semelhante a quem fez tal obra através de suas próprias obras.

Essa noção de que a doutrina e o exemplo servem ao ensino de alguma arte também aparece no relato que Galeno faz sobre o cânone de Policleto: "Pois tendo nos ensinado no seu tratado toda a simetria do corpo, Policleto corroborou seu tratado com uma obra, fazendo uma estátua de acordo com as regras de seu tratado e chamando a própria estátua, como o tratado, de Cânone."10

A écfrase serve como o exemplo da pintura porque ela pode ser vista pelos pintores que aprendem a doutrina e olham como deve ser feita a bela composição através da Calúnia de Apeles. Exatamente por isso ela não é um adendo, porque o exemplo é parte fundamental do discurso ensinando aos pintores o que é uma boa pintura.

\section{Calúnia de Botticelli}

Convém ainda analisar brevemente o trecho da Calúnia cotejando com a famosa versão de Botticelli para vermos um dos usos da pintura de écfrase, procurando identificar os elementos que ressaltamos há pouco. Não sabemos ao certo como Botticelli teve acesso ao texto de Luciano, mas provavelmente ele leu a tradução de Guarino, também usada por Alberti no seu tratado. ${ }^{11}$ Leiamos o trecho em questão (FIGURA 4):

No lado direito dela, está um homem sentado com orelhas muito grandes, quase como as de Midas, estendendo sua mão para a Calúnia enquanto ela ainda está um pouco distante. Ao redor dele, estão duas mulheres, que eu penso ser a Ignorância e a Suspeita. Do outro lado, a Calúnia vem, uma mulher com beleza demais, de certa forma apaixonante e excitante, mostrando como ela está irada e furiosa, ela carrega na mão esquerda uma tocha brilhante e com a outra está arrastando pelos cabelos um jovem que leva as mãos aos céus e pede aos deuses para testemunhar sua inocência. Ela é conduzida por um homem pálido e feio, que tivera um olhar penetrante e parece

${ }^{9}$ Ps.-Cícero, Her. 1.3. $(2005,55)$.

${ }^{10}$ Galeno. De Placitis Hippocratis et Platonis, 448; apud Steiner 2003, 39-40.

${ }^{11}$ Altrocchi 1921. 


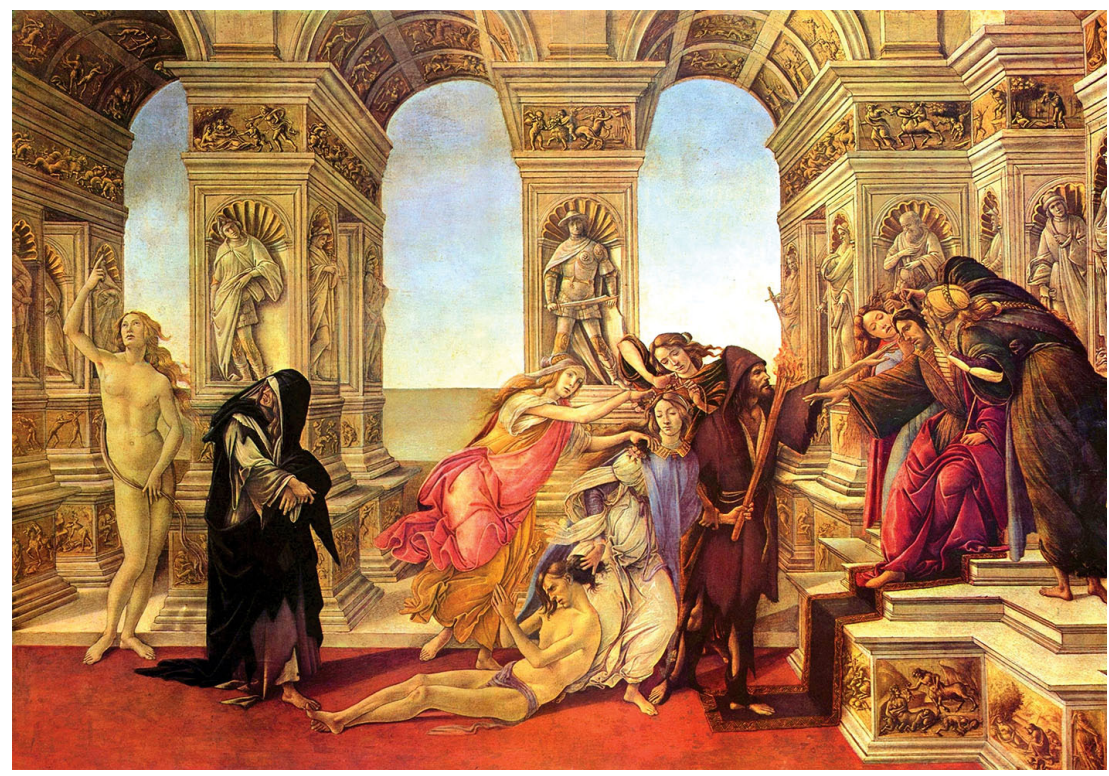

Figura 4. Botticelli, Calúnia de Apeles, têmpera sobre painel, 1494

endurecido por longa doença; supõe-se que ele retrata a inveja. Além disso, há duas mulheres, acompanhantes da Calúnia, cuidando dela, arrumando-a e vestindo-a. De acordo com a informação dada por um interprete da pintura, uma delas é a Intriga e a outra a Fraude. Elas são seguidas por uma mulher vestida toda de luto, de preto e em prantos e ela se chamava Arrependimento. E por fim, ela, cheia de vergonha, estava se virando para trás com lagrimas nos olhos e lançando um olhar ameaçador, para a Verdade que se aproximava. Assim que Apeles imitou na pintura o seu perigo. ${ }^{12}$

A primeira coisa que podemos notar é que a écfrase, como prescreve Nicolau, segue a ordem da pintura indo da direita para a esquerda, descrevendo cada personagem e suas particularidades além de incluir algumas explicações e interpretações sobre essas características, tornando-as vívidas.

Botticelli faz a sua pintura e sua composição inventando a história e suas partes da écfrase de Luciano. Isso quer dizer que as personagens, suas características, seu número e ordem, são inventadas a partir do texto de Luciano. Todos os detalhes descritos estão lá, como as orelhas de Midas. (FIGURA 5) Mesmo assim, a écfrase só serve para a invenção e é restrita à composição. Todo o resto da pintura, o desenho, o uso das luzes e das cores e a perspectiva, tudo isso cabe ao pintor fazer de acordo com os preceitos da pintura.

${ }^{12}$ Lucianus, Cal. 6-9 (Luciano 1961, 367-9). 
Por exemplo, a disposição da pintura segue em parte a écfrase, já que o príncipe está no lado direito, como na descrição de Luciano, e cada personagem está colocada na mesma ordem do texto. Mesmo assim, a pintura deve ser olhada a partir da própria Calúnia, porque o ponto cêntrico está naquele grupo de pessoas (FIGURA 6) e dela pode-se ir em direção ao príncipe com seu julgamento falso ou para a verdade. Sem ousarmos dizer o que isso significa, podemos afirmar que a figura da Calúnia é pensada como a primeira coisa para ser vista, a partir da qual o resto da

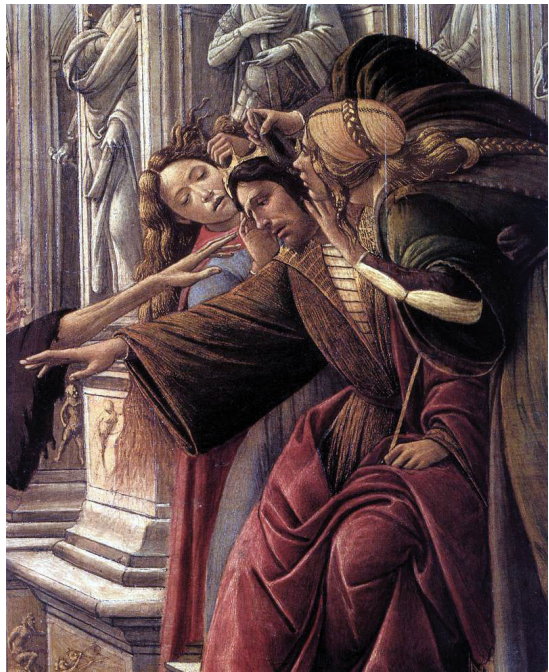

Figura 5. Detalhe das orelhas de Midas. pintura é visto.

Além disso, o pintor usa todos aqueles ornamentos prescritos para deleitar o espectador, fazendo a pintura variada e copiosa. Cada personagem tem suas características físicas, usa uma roupa diferente, está numa

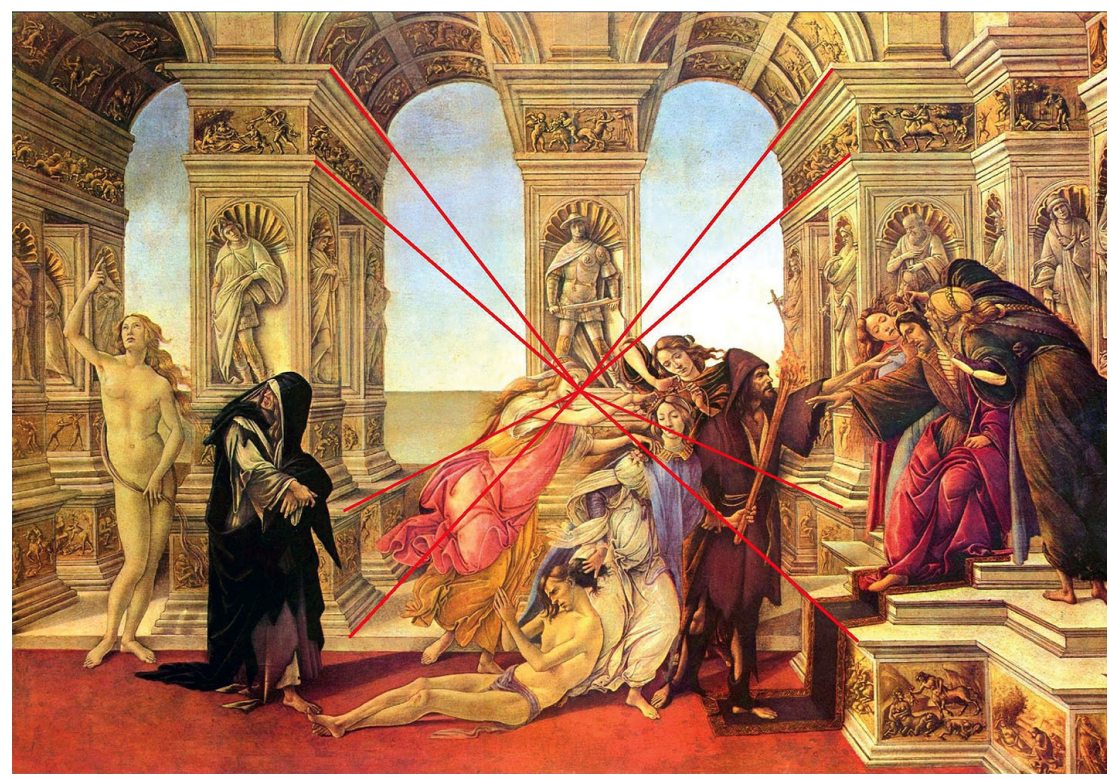

Figura 6. Esquema da construção em perspectiva. 


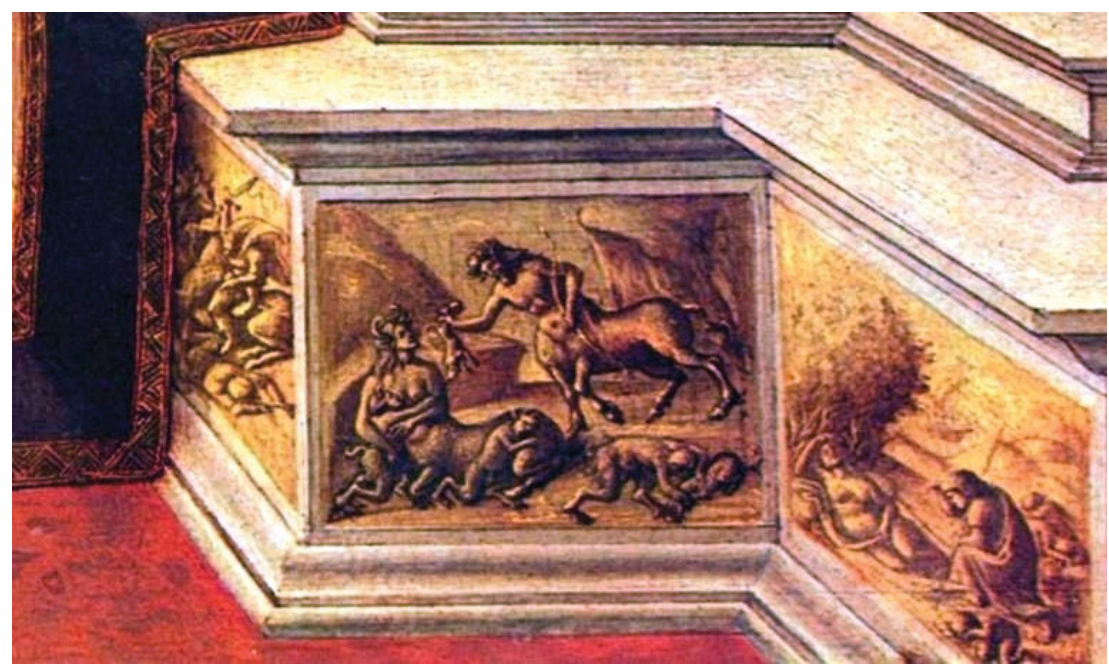

Figura 7. Detalhe da pintura dos Centauros de Zêuxis.

posição, uns estão sentados, outros em pé parados, uns andam, outros são arrastados. Os movimentos e gestos são copiosos e cada um é de uma maneira. E tudo isso torna o espectador atento para aquilo que acontece, pois os olhos vão notando cada detalhe, procurando as diferenças, o que auxilia na hora de aprender a história da Calúnia. Mas vale notar que nenhum deles é inconveniente, porque todos eles estão dentro da medida da própria pintura e daquilo que acontece nela. Pois seria inconveniente que se pintasse as mulheres musculosas como amazonas e que elas estivessem lutando entre si, porque estaria fora da unidade da história apresentada.

Até as arquiteturas são variadas e copiosas com diversos relevos cheios de detalhes. Alguns deles contém sua própria composição, narrando outra história o que causa muito deleite e faz uma pintura dentro da própria pintura. Essas histórias inseridas dentro da história principal também podem ter sua invenção em écfrases. Na Calúnia há um exemplo claro disso logo embaixo do trono do príncipe/rei com outra écfrase de Luciano, presente no texto chamado Zêuxis (FIGURA 7):

Em um prado florido aparece uma mãe Centauro, toda a parte equina está deitada no chão, com os cascos estendidos para trás. A parte humana está levemente levantada nos ombros; os pés da frente não estão estendidos como os outros, pois ela está parcialmente de lado; um deles está inclinado como no ato de ajoelhar, com a pata dobrada; e a outra está começando a alongar e encostar no chão, como na ação de levantar de um cavalo. Das crianças, ela está segurando uma nos braços mamando do modo humano, enquanto o outro olha para os seios da égua como um potro. Na parte superior da pintura, como em uma vista acima, está um Centauro que é claramente o 
marido da mãe que está cuidando das crianças. Ele se inclina, dando risada; e segura um filhote de leão na sua mão direita aterrorizando as crianças. ${ }^{13}$

Botticelli inventou com Luciano ao menos duas partes de sua pintura, a Calúnia de Apeles e os Centauros de Zêuxis. Colocar uma pintura de écfrase dentro de outra pintura de écfrase é algo que nos intriga e que estamos investigando, pois ainda não sabemos o que se propõe com isso, embora vejamos que há uma "rede de referências" que se mostra na pintura. Por fim, podemos dizer que Botticelli não só imita Luciano como emula Apeles, o que o coloca como um igual ou superior aos antigos, retomando a tópica apresentada no prólogo italiano de Alberti de que os italianos superaram os antigos ao conseguirem fazer a pintura renascer.

\section{REFERÊNCIAS}

Alberti, L. B. 1973. Opere Volgari. Bari: Laterza. (Versão digital dos textos latino e italiano organizados por Cecil Grayson, acessada em 29 de julho de 2016: http://www.liberliber.it/mediateca/libri/a/alberti/de_pictura/html/)

Altrocchi, R. 1921. "The Calumny of Apelles in the Literature of the Quattrocento." Publications of the Modern Language Association of America 36(3):454-91.

Luciano. 1961. Lucian 1. Trad. A. M. Harmon. Cambridge, Massachussets: Harvard University Press. (Loeb Classical Edition)

Luciano. 1999. Lucian 6. Trad. K. Kilburn. Cambridge, Massachussets: Harvard University Press. (Loeb Classical Edition)

Ps.-Cicero. 2005. Retórica a Herênio. Tradução de Ana Paula Celestino Faria e Adriana Seabra. São Paulo: Hedra.

Steiner, D. T. 2003. Images in mind: Statues in archaic and classical Greek literature and thought. Princeton University Press.

\section{$*$}

Title. Ekphrasis as painting's example.

Abstract. Some ekphrasis, that described paintings from the greatest masters of antiquity, as Apelles and Zeuxis, have been read and painted on the $15^{\text {th }}$ century. This article aims to show some relationships between painting and ekphrasis, looking into the use that Leon Battista Alberti, on his On Painting, makes of the Calumny of Apelles described by Lucian, electing this ekphrasis as a painting's example. This ekphrasis not only shows the precepts discussed, but also impel the painter to imitate the ancient painting praise. Keywords. Painting; Rhetoric; Ekphrasis; Renassaince; Alberti.

${ }^{13}$ Lucianus, Zeux. 4 (Luciano 1999, 159). 